\title{
Teaching reported speech
}

Dan Raj Regmi

\begin{abstract}
The main purpose of this paper is to analyze the major errors in reported speech made by the learners of Grade XII of Management stream and put forward some practical suggestions for the remedies of those errors. There are a few contributions made by the teachers as well as others interested in teaching reported speech in English to the students speaking languages other than English. Sharma (2002) deals with teaching reported speech in English, which is important for building insights on how effectively we can help the students speaking Nepali master the structural patterns of reported speech in English.
\end{abstract}

Key words: reported speech, tstructures, grammatical items

\section{Introduction}

Up till now no attempt has been made to analyze the similarities and differences between Nepali and English reported speech and their implications in teaching reported speech in English. There are a number of grammatical structures to be taken into consideration both by the teachers and students equally in the teaching/learning of the reported speech in both Nepali and English. Reported speech is one of the main grammatical items to be mastered by the students of standard XII and one of the major test items in grammar, normally, to be asked in the examinations. We teach this grammatical item to get the students acquainted with the structure and functions of the reported speech in English and enable them to use it in their real life situations communicatively. However, in reality the English teachers find difficulties in enabling the learners to master the forms and functions of the reported speech in English and the Nepali-speaking learners encounter difficulties in using the English reported speech correctly, fluently and communicatively in their real life situations.

This paper is organized into five sections. In section 1.2, we will briefly deal with some of the basic similarities and differences between Nepali and English reported speech. Section 1.3 analyzes the major errors in reported speech made by the learners. In section 1.4, we will try to explore the reasons for the errors in the reported speech. In section 1.5, we suggest some practical ways to help the learners to master the processes of reported speech.

\section{Reported speech in English and Nepali}

Reported speech is not the fundamental characteristic of Nepali. In spoken Nepali, direct speech is used more often than indirect speech in natural conversation; the use of indirect speech increased only after the recent rise in mass media (Adhikary, 2055 BS). However, there are some fundamental similarities and marked differences in the formation of reported speech in English and Nepali. While shifting from direct to reported speech in both languages, i.e. English and Nepali, we require a number of grammatical changes to be made to the original text.

In Nepali, reported speech may occur either after reporting verb or before reporting verb or in between the subject of the matrix clause and reporting verb. Following are some examples: 
(1)

\section{a. Post-reporting verb}

usale ke $b^{\mathrm{h}}$ anyo $\mathrm{b}^{\mathrm{h}}$ ane $\mathrm{u}$ aj ${ }^{\mathrm{h}}$ ai $\mathrm{k}^{\mathrm{h}} \mathrm{elc}^{\mathrm{h}} \mathrm{a}$

'He said that he would still play.'

\section{b. Pre-reporting verb}

$\mathrm{u}$ aj ${ }^{\mathrm{h}}$ ai $\mathrm{k}^{\mathrm{h}} \mathrm{elc}^{\mathrm{h}} \mathrm{a} \mathrm{b}^{\mathrm{h}}$ ani usale $\mathrm{b}^{\mathrm{h}}$ anyo

'He said that he would still play.'

\section{c. Clause internally}

usale $u$ aj ${ }^{\mathrm{h}}$ ai $\mathrm{k}^{\mathrm{h}} \mathrm{elc}^{\mathrm{h}} \mathrm{a} \mathrm{b}^{\mathrm{h}}$ anyo

'He said that he would still play.'

In (1a-c) the basic free translation is almost the same though it is possible to interpret these three sentences as having different pragmatic implications because the change in word order triggers a change in meaning in Nepali (Regmi, 2008). In English the reported speech occurs only after the reporting verbs, as in (2).

(2) He said that he would still play.

In Nepali, normally the inverted commas are removed and the reported speech clause is combined with the matrix clause with the conjunctions like ke $b^{h}$ ane, kaso $b^{h}$ ane, $b^{h}$ ani and $b^{h}$ anera, as in (3).

(3) timile hĩjo $b^{\mathrm{h}}$ anyau, "ma $\mathrm{g}^{\mathrm{h}}$ aramai basc ${ }^{\mathrm{h}} \mathrm{u}$."

$\rightarrow$ timile hĩjo ke $b^{h^{h}}$ anyau $b^{h^{h}}$ ane timi $g^{h}$ haramai basc ${ }^{h}$ hau.”

[What you said yesterday is you stay at home.]

Looking at (3) it occurs that in Nepali 'back shift' is not as obligatory as in English.

In Nepali, as in English the reporting verb $b^{\mathrm{h}} n n u$ is normally changed into bataunu, $\mathrm{t}^{\mathrm{h}} \mathrm{annu}$, mannu, sod ${ }^{\mathrm{h}}$ nu, darsaunu, araunu, jnaunu, aulaunu, kura garnu, s pashta garnu, byakta garnu, swikar garnu, asha garnu , prashna garnu, etc. according to the 'sense' of the reported speech (Sharma, 2057BS).

In both English and Nepali, the personal pronouns of the reported speech have to be changed. Normally, the second person is changed according to the object of the reporting verb whereas the first person is changed according to the subject of the reporting verb. The third person personal pronouns are not changed at all.

As in English, Nepali proximal demonstratives and deictic adverbs are changed into distal forms.

(4) proximal

distal

yo, yi, yini, yiniharu

tyo, ti, tini, tiniharu/ u, uni, uniharu,

yasto, yeti, yahã, yata

tyasto, tyati, tyaña, tyata,

ysari, yaso, yastai

tyasari, tyasto, ustai, tyastai

In Nepali, the time adverbials may be changed as in English. However, it is not as obligatory as in English. In Nepali, though they are changed, there is a lack of specific words as in English.

(5) bimalale malai bhanin, " $b^{\mathrm{h}}$ oli hari mero $\mathrm{g}^{\mathrm{h}}$ arama a $\tilde{u c}^{\mathrm{h}} \mathrm{a} . "$

$\rightarrow$ bimalale malai aja hari unaka $\mathrm{g}^{\mathrm{h}}$ arama aune batai n.

We observe a number of similarities and differences in between these two languages in terms of major grammatical changes in reported speech. Table1 presents the similarities and differences between English and Nepali reported speech.

Table 1: Similarities and differences between English and Nepali reported speech

\begin{tabular}{|c|c|c|c|}
\hline & $\begin{array}{c}\text { Major grammatical } \\
\text { changes }\end{array}$ & English & Nepali \\
\hline 1 & Reporting Verbs* & $\sqrt{ }$ & $\sqrt{ }$ \\
\hline 2 & Verb Tenses & $\sqrt{ }$ & $\times$ \\
\hline 3 & $\begin{array}{c}\text { Pronouns and possessive } \\
\text { determiners }\end{array}$ & $\sqrt{ }$ & $\sqrt{ }$ \\
\hline 4 & $\begin{array}{c}\text { Demonstratives and deictic } \\
\text { adverbs }\end{array}$ & $\sqrt{ }$ & $\sqrt{ }$ \\
\hline 5 & Time adverbials* & $\sqrt{ }$ & $\sqrt{ }$ \\
\hline 6 & Questions & $\sqrt{ }$ & $\times$ \\
\hline
\end{tabular}

* Not regular in Nepali

\section{Analysis of the major errors}

In this section, we analyze errors in the reported speech in English from the test papers of the learners of Grades XII of Management stream. After the interval of teaching of the forms and functions of the reported speech to the students interactively with the major language skills a test was adminis- 
tered in 42 students on the reported speech.

This analysis is primarily based on classification of errors in relation to the very basic grammatical changes to be made in shifting from the direct speech to the indirect speech in standard English and trying to provide the explanation for the errors as far as possible. The general perspective of the analysis is basically functional and pedagogical. Tentatively, the errors committed by the students are related to the following aspects of the general rules of the reported speech.

\section{(1) Reporting verbs}

In English, the reporting verb 'said' or 'said to' is obligatorily changed into the forms such as told, requested, asked, prayed, wished, exclaimed according to the structural patterns of the sentences as given in (6).

(6)

\begin{tabular}{|l|l|l|}
\hline $\begin{array}{l}\text { sentence } \\
\text { types }\end{array}$ & $\begin{array}{l}\text { reporting verb } \\
\text { (direct } \\
\text { speech) }\end{array}$ & $\begin{array}{l}\text { reporting verb (indi- } \\
\text { rect speech) }\end{array}$ \\
\hline declarative & said/said to & said/told \\
\hline Imperative & said/said to & $\begin{array}{l}\text { requested/command- } \\
\text { ed/ordered/ } \\
\text { proposed/suggested/ } \\
\text { forbade/ }\end{array}$ \\
\hline Interrogative & said/said to & Asked \\
\hline Exclamatory & said/said to & $\begin{array}{l}\text { exclaimed with joy/ } \\
\text { sorrow/surprise }\end{array}$ \\
\hline optative & said/said to & wished/prayed \\
\hline
\end{tabular}

There are also erroneous sentences in relation to the reporting verb in the indirect speech. One of them is given in (7).

(7)

a. Hari said, "I am writing a letter to Sita now."

*Hari told that he was writing a letter to Sita that time.

\section{(2) Verb tenses}

In English verb tenses require to be obligatorily changed since in reported speech we usually talk about a time in the past (because obviously the person who spoke originally spoke in the past). A popular rule referred to as back-shift of tense is usually required unless the situation has not changed. The pattern of the tense change is given in (8).
(8)

\begin{tabular}{|c|c|}
\hline Direct speech & Indirect speech \\
\hline Present simple & Past simple \\
\hline Present continuous & Past continuous \\
\hline Present perfect simple & Past perfect simple \\
\hline Present perfect continuous & Past perfect continuous \\
\hline Past simple & Past perfect \\
\hline Past continuous & Past perfect continuous \\
\hline Past perfect & Past perfect \\
\hline Past perfect continuous & Past perfect continuous \\
\hline
\end{tabular}

Some of the students have produced the following erroneous sentences as in (9)

(9)

a. Ram said to Sita, "I love you but you do not love me."

* Ram told to Sita that he love her but she do not love me.

b. Ram said to Sita, "I wrote a letter yesterday."

*Ram told Sita that he wrote a letter the day before.

c. Anita said, "I had completed my course before I returned to Kathmandu."

* Anita told that she have completed her course before I return to Kathmandu.

d. Alisha said to Anjan, "We had been studying together for few years."

* Alisha told to me that they have been studying together for few years.

e. Hari said, "I am writing a letter to Sita now.

* Hari told me that I am writing a letter to Sita now.

f. Ram said to Sita, "I wrote a letter yesterday."

* Ram told Sita that he was writing a letter the previous day.

g. Ram said, "Does Sita complete her job?”

* Ram asked If Sita complete her job.

h. Anita, "When does this program end?"

* Anita asked if when this program end.

Ali said, "How did you go across the river?"

* Ali asked if How did I went across the river.

j. Gita said, "Are you going to take an exam?”

* Gita said me am I going to give an exam. 
k. Sanju said, "Where is your house?"

* Sanju asked where is my house.

1. Ram said, "Aha! My mom is coming from Palpa tomorrow?"

* Ram exclaimed with joy that his mom is coming the following day.

In examples (9a-l), though there are also other types of error, the main errors are related to backshift.

\section{(3) Pronouns and possessive determiners}

In reported speech pronouns and possessive determiners may necessitate to be changed when the speaker or listener changes. One has to be very careful with personal pronouns. They require to be changed according to the situation. As we said earlier as in case of Nepali the first person pronoun of the indirect speech is changed according to the subject of the reporting verb whereas the second person is changed according to the object of the reporting verb. The third person does not change. The students have produced erroneous sentences in this respect as well.

(10)

a. Sanju said, "Where is your house?"

* Sanju asked where was your house.

b. Sita said, "May you pass the exam?"

*Sita wished that you might pass the exam.

c. He said, "Please, help me!"

*He asked me to help me.

\section{Demonstratives and deictic adverbs}

The demonstratives and deictic adverbs, such as this, these, here, now, and today, may need to be replaced by more remote forms such as that, those, there, then, and that day or by a more direct reference to the place or time. Some of the students have produced the following erroneous sentences as in (11)

(11) Anita said, "When does this programme end?"

*Anita asked when did this programme end.

\section{Questions}

It is a quite common rule that while reporting questions the word order requires to be changed to that of a statement, namely subject-verb, and the auxiliary verb do is dropped. Moreover, the yes/ no questions start with if, or whether and wh-word questions, such as why, when, and where, however, do not.

\section{(12)}

a. Anita said, "When does this programme end?"

*Anita asked when did that programme end.

b. Ram said, "Does Sita complete her job?"

*Ram asked did Sita had completed her job.

c. Soniya said, "Where is your house?"

*Soniya asked where was your house.

d. Ali said, "How did you go across the river?"

* Ali asked how do I go across the river.

e. Anita said, "When does this programme end?"

*Anita asked when does the programme ends.

f. Gita said, “Are you going to take an exam?"

${ }^{*}$ Gita asked me am I going to take an exam?

The erroneous formations in (12a-f) are related with shifting questions from direct speech to indirect speech in English.

We can also show the real phenomenon of the errors made by the learners statistically. ${ }^{1}$ Table 2 presents the total number of test items in different structural patterns of sentences in English.

Table 2: Test items in different structural patterns

\begin{tabular}{|c|c|c|c|}
\hline Sentence types & $\begin{array}{c}\text { No. of } \\
\text { test } \\
\text { items }\end{array}$ & $\begin{array}{c}\text { No. of total } \\
\text { answers }\end{array}$ & Remarks \\
\hline Declarative & 8 & 236 & \\
\hline Imperative & 4 & 168 & \\
\hline Interrogative & 5 & 210 & \\
\hline $\begin{array}{c}\text { Exclamatory/ } \\
\text { Optative }\end{array}$ & 4 & 168 & \\
\hline Total & 21 & 782 & \\
\hline
\end{tabular}

Table 2 shows that the total number of the test items was 21 covering all the major sentence types

1 The learners belong to Bagmati Modern

College (Bagmati Higher Secondary School), Naxal, Kathmandu 
in English (declarative, imperative, interrogative, exclamatory and optative). The total number of the answers in different structural patterns amounts to 782.

Table 3 presents the number of errors in different structural patterns of sentences with respect to the different grammatical elements to be taken into consideration while changing into reported speech.

Table 3: Errors in sentence patterns and grammatical element

\begin{tabular}{|c|c|c|c|c|c|}
\hline $\begin{array}{c}\text { Grammatical ele- } \\
\text { ments/Sentence } \\
\text { types }\end{array}$ & $\begin{array}{c}\text { Report- } \\
\text { ing } \\
\text { verbs } \\
\text { (RV) }\end{array}$ & $\begin{array}{c}\text { Verb } \\
\text { Tenses } \\
\text { (VT) }\end{array}$ & $\begin{array}{c}\text { Pronouns } \\
\text { and posses- } \\
\text { sive } \\
\text { determiners } \\
\text { (PPD) }\end{array}$ & $\begin{array}{c}\text { Demon- } \\
\text { stratives } \\
\text { and } \\
\text { deictic } \\
\text { adverbs } \\
\text { (PDA) }\end{array}$ & $\begin{array}{c}\text { 'Deviat- } \\
\text { ed struc- } \\
\text { tures' } \\
\text { (STR) }\end{array}$ \\
\hline Declarative(DECL) & 18 & 76 & 3 & 4 & 3 \\
\hline Imperative (IMP) & 12 & 4 & 2 & 6 & 1 \\
\hline Interrogative (INT) & 8 & 36 & 6 & 6 & 42 \\
\hline $\begin{array}{c}\text { Exclamatory/ } \\
\text { Optative (EXCL) }\end{array}$ & 6 & 18 & 2 & 4 & 22 \\
\hline Total & 44 & 134 & 13 & 20 & 68 \\
\hline
\end{tabular}

Table 3 clearly shows the learners have committed the highest number of errors in changing the patterns of tenses and the least number of errors in the case of pronouns and possessives. The table also presents that the learners have problems in the case of reporting verb. They have also problem in the change of reporting verb especially in the imperative where the reporting verb is changed according to the sense of the reported speech. The number of the deviated structures is also considerable. This situation may be presented in the following diagram.

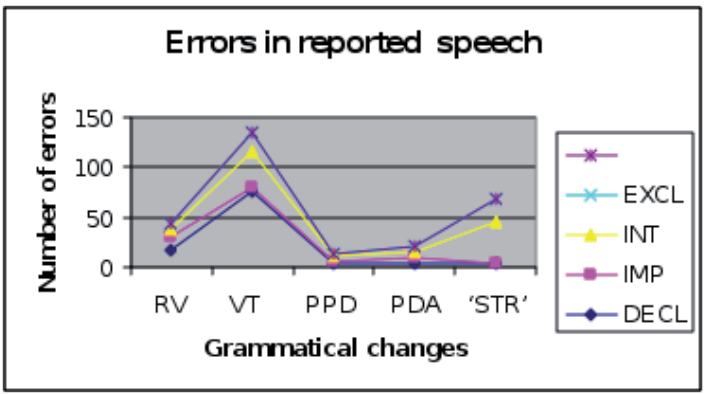

Diagram 1: Errors in sentence patterns and grammatical elements

The diagram 1 presents basically three major concerns. The first is the case of the change of reporting verbs in different sentence patterns. The number of the errors committed by the learners is also considerable. The second is the case of the change of tenses in different sentence patterns. The number of the errors committed by the learners is the highest. The third is the production of structurally deviated structures by the learners. This is also a serious matter.

\section{Reasons for the errors}

Nepali learners have considerable trouble in shifting direct speech to indirect speech in English and learning to use it communicatively due to a number of reasons. These reasons can be broadly categorized into general and specific reasons.

\section{General reasons}

One of the main reasons for difficulties in the reported speech is the grammatical elements to be taken into account in the reported speech. These errors particularly pose difficulty because there are students from a variety of different backgrounds, with different personal and professional interests, and different motivations for learning English. Moreover, they normally do not use the reported speech outside the classroom. Undoubtedly, they require a clear and effective context to present reported speech in a variety of situations, rather than in a single context.

\section{Specific reasons}

The specific reasons are grounded on the dissimilarities between Nepali and English reported speech. The basic assumptions in contrastive analysis are that the similarities are equated with ease and dissimilarities are equated with difficulties in learning. However, Agnihotri (1988) assumes that the errors in the second language are learning strategies depending on the learners and his/her socio-psychological background rather than instances of mother tongue interference. In this respect, we may make some predictions with respect to difficulties in shifting direct speech to the indirect speech.

i. As Nepali lacks strict back shift in the formation of the reported speech, most of the serious mistakes are related to the change of the tense in the reported speech in English. 
ii. There are mistakes in the reporting of questions in English. The reason is that in Nepali while reporting questions the word order does not need to be changed to that of a statement, namely subject-verb. However, in English while reporting questions, the word order requires to be changed to that of a statement, namely subject-verb, and the auxiliary verb $d o$ is dropped. Moreover, the yes/no questions start with if, or whether and wh-word questions, such as why, when, and where, however, do not.

\section{Some suggestions}

The learners, teachers, syllabus designers, textbook writers and supplementary material producers are roleplayersintheteaching andlearning process. The main role of these agents is to assist the teachers and the learners. Effective teaching and learning is impossible without the proper co-ordination between the role players and the knowledge of the linguistic background of the learners. The following suggestions may help the Nepali speaking learners master the formation of the reported speech in English.

(1) While designing the syllabus of English for the Nepali learners significant distinct characteristics of English reported speech should be taken into consideration.

(2) While writing the textbooks of English the reported speech should be presented in such a way that the learners can easily master the process of back shift and the process of changing the questions in to reported speech in English.

(3) Keeping in view the dissimilarities between English and Nepali reported speech and the errors made by the learners in the formation of the reported speech in English we are required to describe and explain the structures of the reported in detail and appropriate exercises should be provided for the practice of the structures.

(4) In the context of Nepal where English is mostly taught in the mother tongue we should slightly modify the way of the presentation and practice of the grammatical items. The teacher besides enabling the learners to conceptualize the functions of the reported speech in appropriate situations he/ she should make them practice the structures so that they will not make errors in the formation of reported in English.

(5) The prescribed textbook does not provide enough exercises for the reported speech. While teaching the reported speech the focus should be in the teaching and practice of tense change and the 'structures' of reporting of direct questions in reported speech. The students should be provided enough exercises especially in tense change for the students.

Dr. Dan Raj Regmi is Associate Professor and Head of Central Department Linguistics, Tribhuvan University, Nepal. Dr. Regmi has been teaching linguistics for over two decades. $\mathrm{He}$ completed $\mathrm{PhD}$ in linguistics from Tribhuvan University, Nepal, writing a dissertation on Bhujel, an endangered and previously undescribed Tibeto-Burman language of Nepal within the framework of functional-typological grammar. He has authored and coauthored a number of English grammars and practice books based on the communicative approach and other teaching materials for school and campus level students. Dr. Regmi has a number of articles and papers published in various journals.

\section{References}

Adhikary, H. (2055 BS). Samasamyik Nepali Byakarana (A Contemporary NepaliGrammar). Kathmandu: Bidhyarthi Pustak Bhandar

Agnihotri, R.K. (1988). Errors as learning strategies. In Ujjal Singh Bhari (ed.) Indian Journal of Applied Linguistics, Vol. 14: 1

Regmi, D.R. (2008). Clause Structure in Standard Nepali. Kathmandu: The Sunlight Publications

Sharma, B. (2002). Teaching reported speech in English, inductively and deductively: A practical study. An M Ed dissertation in English, Tribhuvan University.

Sharma, M. R. (2000).VS. Shabdarchana ra barnabinyas (Word formation and writing system in Nepali). Kathmandu: Nawin Prakashan 